Instructions/Template for Preparing Manuscript for Jendela Nursing Journal

\title{
Brain Gymnastic Decreases Dementia Levels in the Elderly
}

\author{
Sahrul Widyastuti ${ }^{1}$, Budi Widiyanto ${ }^{1}$, Arwani $^{1}$ \\ ${ }^{1}$ Nursing Department, Poltekkes Kemenkes Semarang \\ Corresponding author: sahrulwidyastuti@gmail.com
}

\begin{abstract}
Background: Dementia (senility) is a condition where somebody examine the decrease in memory and thinking ability, and this ability causing daily life disorder. The number of elderly who has dementia from year by year showed an increase. Dementia that is not treated properly will get worse to Alzheimer's. However, until now there has been no research that shows in what age range brain exercise has an effect or impact to reduce the level of dementia in the elderly.

Purpose: To analyze the effect of brain gymnastics on decreasing the level of dementia in different elderly groups.

Methods: The research design was quasi experimental with non-randomized control group. The number of respondents was 45 respondents. The respondents were intervented with brain gymnastic. The instrument used was a Mini Mental State Examination (MMSE) questionnaire. Data were analised using kruskal wallis and Mann Whitney test.

Results: The results of the three groups research before and after given brain gymnastics showed that there were significant changes. Old elderly make a significant difference with a $p$ value of $0,000(p<0.05)$. Mann Whitney test result obtained pre and old elderly with $p$ value $<0.001$.
\end{abstract}

Conclusion: Brain gymnastics affects the decrease level of dementia in different age groups of elderly.

\section{Keywords:}

Dementia Level; Elderly; Brain Gymnastics.

\section{LATAR BELAKANG}

Demensia (pikun) adalah keadaan dimana seseorang mengalami penurunan kemampuan daya ingat dan daya pikir, dan kemampuan tersebut menimbulkan gangguan terhadap fungsi kehidupan sehari- hari ditandai dengan penurunan kongnitif, perubahan mood, dan tingkah laku sehingga mempengaruhi aktivitas kehidupan sehari- hari (Azizah, 2011). sehingga mempengaruhi aktivitas kehidupan sehari- hari (Azizah, 2011). 
Demensia biasanya terjadi secara perlahan sehingga yang mengalami tidak menyadarinya dan pada umumnya semakin parah menjadi demensia Alzheimer. Bukannya menurun, tren penderita demensia Alzheimer di Indonesia semakin meningkat setiap tahunnya (Kementrian Kesehatan Republik Indonesia, 2017).

Data dari World Alzheimer's Report tahun 2013 memprediksi bahwa jumlah lansia dengan demensia akan meningkat dari 101 juta menjadi 277 juta ditahun 2050. Sementara di Indonesia diperkirakan sekitar $15 \%$ dari penduduk lansianya mengalami demensia (Santoso, 2002 dalam Maharyani, 2010). Sedangkan demensia yang tidak ditangani akan semakin parah menjadi Alzheimer, jumlah penderita penyakit Alzheimer sekitar 46 juta jiwa di dunia dan sebanyak 22 juta jiwa diantaranya berada di asia. Estimasi jumlah penderita penyakit Alzheimer di Indonesia pada tahun 2013 mencapai satu juta orang. Jumlah ini diperkirakan akan meningkat drastis menjadi dua kali lipat pada tahun 2030, dan menjadi empat juta orang pada tahun 2050 (Alzheimer's Disease International, 2013).

Demensia biasanya terjadi pada lansia, hal ini berkaitan dengan pencapaian kematangan dan ukuran sel sehingga menimbulkan kemunduran dan kelemahan dari waktu ke waktu (Rosita, 2012). Masalah kesehatan yang meliputi kemunduran dan kelemahan pada lanjut usia salah satunya adalah perubahan kongnitif, yaitu perubahan memori atau daya ingat. Pada lansia daya ingat merupakan salah satu fungsi kongnitif yang sering kali paling awal mengalami penurunan.

Kemunduran yang terjadi dapat diatasi dengan berbagai cara. Menurut penelitian yang dilakukan Guslinda (2013), mengatakan bahwa beragam pengobatan dapat diterapkan pada pasien demensia. Mulai dari terapi farmakologis seperti rehabilitasi medik berupa fisioterapi, latihan, kongnitif, terapi wicara dan terapi okupasi, hingga terapi non farmakologis yang dilakukan dengan menerapkan perilaku sehat dan stimulasi otak sedini mungkin menggunakan beragam terapi seperti rekreasi, membaca, mendengarkan musik, mengingat waktu dan tempat, berdansa, terapi seni dan senam otak untuk melatih kemampuan otak bekerja.

Senam otak memiliki berbagai manfaat. Menurut Maryam (2008), seseorang yang melakukan senam secara teratur dan benar dalam jangka waktu yang cukup dapat memperlambat proses degenerasi karena perubahan usia, membentuk berbagai sikap kejiwaan, dan memberikan rangsangan bagi saraf-saraf yang lemah pada lansia. Senam otak merupakan serangkaian latihan gerak sederhana yang membantu mengoptimalkan fungsi dari segala macam pusat yang ada di otak manusia. Senam ini dapat memperlancar aliran darah dan oksigen ke otak, meningkatkan daya ingat dan konsentrasi, meningkatkan energi tubuh, mengatur tekanan darah, meningkatkan penglihatan, keseimbangan jasmani, dan juga koordinasi. Senam otak dapat dilakukan segala umur, baik lansia, bayi, anak autis, remaja, maupun orang dewasa (Anggriyana dan Atikah, 2010). Hasil penelitian yang dilakukan Guslinda, (2013), didapatkan hasil bahwa senam otak dapat meningkatkan fungsi kongnitif pada lansia dengan demensia dengan nilai $p$-value $=0,000$. Dengan demikian dapat dikatakan bahwa senam otak berpengaruh terhadap daya ingat lansia dengan demensia. Menurut penelitian Sarifah (2016), senam otak (Brain Gym) dapat menurunkan tingkat demensia pada lansia. 
Namun demikian hingga saat ini belum ada penelitian yang menunjukkan pada rentang umur berapa senam otak memberikan efek atau dampak untuk menurunkan tingkat demensia pada lansia. Oleh karena itu penelitian ini akan difokuskan pada kelompok umur lansia.

\section{TUJUAN}

Tujuan dari penelitian ini adalah untuk menguji pengaruh senam otak terhadap penurunan tingkat demensia pada kelompok umur lansia yang berbeda.

\section{METODE}

Penelitian ini menggunakan desain penelitian quasy eksperimental. Penelitian ini dilakukan pada bulan Maret sampai April 2019. Populasi pada penelitian adalah penderita demensia di Wisma Lansia Harapan Asri Banyumanik Semarang sebanyak 45 orang. Teknik non randomized control group design dengan total sampling.

Kriteria inklusi pada penelitian ini adalah pra lansia berusia 45- 59 tahun, usia lansia 6074 tahun, dan lansia tua 75-90 tahun, lansia aktif dan mandiri, dapat mendengar dan melihat. Instrumen pada penelitian ini adalah kuesioner Mini Mental State Examination (MMSE) (Notoatmodjo, 2010). Analisa data dengan menggunakan uji Kruskal Wallis dan uji Post Hoc Mann-Whitney.

\section{HASIL}

Tabel 1 Distribusi karakteristik responden berdasarkan usia dan jenis kelamin pada lasia dengan demensia $(n=45)$

\begin{tabular}{lcrrr}
\hline \multirow{2}{*}{$\begin{array}{c}\text { Karakteristik } \\
\text { Responden }\end{array}$} & \multicolumn{3}{c}{ Kelompok Intervensi } & \\
\cline { 2 - 4 } & Pra Lansia & Lansia & $\begin{array}{c}\text { Lansia } \\
\text { Tua } \\
(n=15)\end{array}$ & $p$ \\
\hline Usia (mean \pm SD) & $58,13 \pm 1,12$ & $67,73 \pm 4,66$ & $79,53 \pm 2,32$ & 1,00 \\
Jenis Kelamin & & & & \\
n (\%) & $7(46,7)$ & $7(46,7)$ & $7(46,7)$ & \\
Laki - laki & $8(53,3)$ & $8(53,3)$ & $8(53,3)$ & \\
Perempuan & & & \\
\hline
\end{tabular}

Berdasarkan tabel 1menunjukkan bahwa rata-rata usia pada kelompok pra lansia 58,13, rerata pada kelompok lansia 67,73 dan rerata pada kelompok lansia tua 79,53. Secara statistik karakteristik responden berdasarkan usia dan jenis kelamin adalah homogen $p>0,05$. 
Tabel 2 Distribusi frekuensi tingkat demensia pada kelompok umur lansia sebelum dan setelah diberikan senam otak $(n=45)$

\begin{tabular}{|c|c|c|c|c|c|c|c|}
\hline \multirow{3}{*}{\multicolumn{2}{|c|}{$\begin{array}{l}\text { Kelompok } \\
\text { Intervensi }\end{array}$}} & \multicolumn{6}{|c|}{ Tingkat Demensia } \\
\hline & & \multirow{2}{*}{\multicolumn{2}{|c|}{$\begin{array}{l}\text { Definitif } \\
\text { cognitive }\end{array}$}} & \multirow{2}{*}{\multicolumn{2}{|c|}{$\begin{array}{l}\text { Probable } \\
\text { cognitive }\end{array}$}} & \multirow{2}{*}{\multicolumn{2}{|c|}{ Normal }} \\
\hline & & & & & & & \\
\hline \multirow{3}{*}{ Pra lansia } & & & & & & & \\
\hline & pre & 0 & 0 & 15 & 100 & 0 & 0 \\
\hline & post & 0 & 0 & 6 & 40 & 9 & 60 \\
\hline \multirow[t]{2}{*}{ Lansia } & pre & 0 & 0 & 15 & 100 & 0 & 0 \\
\hline & post & 0 & 0 & 13 & 86,7 & 2 & 13,3 \\
\hline \multirow[t]{2}{*}{ Lansia tua } & pre & 1 & 6,7 & 14 & 93,3 & 0 & 0 \\
\hline & post & 1 & 6,7 & 13 & 86,7 & 1 & 6,7 \\
\hline
\end{tabular}

Berdasarkan Tabel 2 menunjukkan bahwa tingkat demensia definitif cognitive setelah diberi senam otak pada kelompok pra lansia tidak ada, pada kelompok lansia tidak ada dan pada kelompok lansia tua sebanyak 1 responden $(6,7 \%)$. Sedangkan tingkat demensia probable cognitive pada kelompok pra lansia sebanyak 6 responden $(40 \%)$, lansia 13 responden $(86,7 \%)$, dan lansia tua 13 responden (86,7\%). Untuk tingkat demensia normal pada kelompok pra lansia sebanyak 9 responden $(60 \%)$, lansia sebanyak 2 responden $(13,3 \%)$, dan lansia tua sebanyak 1 responden $(6,7 \%)$.

Distribusi frekuensi tingkat demensia pada kelompok umur lansia sebelum dan setelah diberi intervensi senam otak dapat dilihat pada tabel dibawah ini.

Tabel 3 Gambaran skor demensia pada kelompok umur lansia sebelum dan sesudah diberikan senam otak $(n=45)$

\begin{tabular}{lccc}
\hline Kelompok & \multicolumn{3}{c}{ Skor demensia } \\
\cline { 2 - 4 } Intervensi & $\begin{array}{c}\text { Sebelum } \\
\text { median,min-max }\end{array}$ & $\begin{array}{c}\text { Setelah } \\
\text { median,min-max }\end{array}$ & $p$ \\
\hline Pra lansia & $22,18-23$ & $25,19-28$ & 0.010 \\
Lansia & $20,17-22$ & $20,19-25$ & \\
Lansia tua & $19,16-20$ & $19,16-25$ & \\
\hline
\end{tabular}

Tabel 3 menunjukkan hasil nilai median kelompok pra lansia sebelum dilakukan intervensi adalah 22 dan setelah dilakukan intervensi adalah 25. Pada kelompok lansia nilai median sebelum dilakukan intervensi 20 dan setelah intervensi adalah, sedangkan pada kelompok lansia tua nilai median sebelum diberi intervensi adalah 19 dan setelah diberi intervensi adalah 19. 
Tabel 4 Uji Kruskal Wallis perbedaan skor demensia pada kelompok umur lansia sebelum dan setelah diberi senam otak

\begin{tabular}{lccc}
\hline \multicolumn{1}{c}{$\begin{array}{c}\text { Kelompok } \\
\text { Intervensi }\end{array}$} & $n$ & Mean Rank & $p$ value \\
\hline Pre & 15 & 31,60 & $<0,001$ \\
Pra Lansia & 15 & 24,00 & \\
Lansia & 15 & 13,40 & \\
Lansia Tua & & & \\
Post & 15 & 34,13 & \\
Pra Lansia & 15 & 23,60 & \\
Lansia & 15 & 11,27 & \\
Lansia Tua & & & \\
\hline
\end{tabular}

Tabel 4 menunjukkan hasil analisis perbedaan skor demensia sebelum dan setelah diberi senam otak. Karena data tidak berdistribusi normal maka dilakukan transformasi data tetapi data tetap tidak berdistribusi normal, sehingga dilakukan uji alternatif Kruskal Wallis. Didapatkan nilai $p<0,001$, maka dapat ditarik kesimpulan bahwa ketiga kelompok memiliki perbedaan yang signifikan sebelum dan setelah diberi senam otak.

Tabel 5 Analisis Uji Mann Whitney Perbedaan pada Kelompok Umur Sebelum dan Setelah Diberi Senam Otak

\begin{tabular}{lc}
\hline \multicolumn{1}{c}{ Kelompok } & $p$ value \\
\hline Pra Lansia vs Lansia & 0,003 \\
Pra Lansia vs Lansia Tua & $<0,001$ \\
Lansia vs Lansia Tua & 0,001
\end{tabular}

Tabel 5 uji Man Whitney menunjukkan bahwa secara statistik sebelum dan setelah diberi senam otak ketiga kelompok berubah secara bermakna. Karena pra lansia vs lansia berbeda, pra lansia vs lansia tua berbeda, dan lansia vs lansia tua juga berbeda yang membuat angka menjadi kecil yaitu lansia tua karena ketika semua di vs dengan lansia tua tingkat signifikan menjadi lebih kecil. Sehingga dapat disimpulkan bahwa lansia tua membuat hasil perbedaan yang signifikan dengan nilai $p<0,001$.

\section{PEMBAHASAN}

\section{Karakteristik Responden}

Berdasarkan penelitian didapatkan bahwa data lansia di Wisma Lansia Harapan Asri dengan jenis kelamin laki- laki pada kelompok pra lansia sebanyak 7 responden $(46,7)$, kelompok lansia 7 responden $(46,7)$ dan kelompok lansia tua 7 responden $(46,7)$. Sedangkan untuk jenis kelamin perempuan pada kelompok pra lansia sebanyak 8 responden $(53,3)$, lansia 8 responden $(53,3)$, dan lansia tua 8 responden $(53,3)$. Hasil observasi peneliti ini dengan penelitian Rekawati (2004), yang menyatakan bahwa 
usia harapan hidup perempuan lebih lama dibandingkan dengan laki-laki. Semakin tinggi usia harapan hidup perempuan maka semakin lama kesempatan lansia perempuan untuk hidup, sehingga semakin besar kemungkinan mengalami demensia.

Perempuan lebih berisiko mengalami penurunan kognitif dibandingkan laki - laki ketika memasuki usia lanjut. Hal tersebut disebabkan karena perbedaan anatomis maupun fisiologis, dimana secara fisik laki- laki struktur tubuh yang lebih besar daripada perempuan (Kartinah, Komariyah, \& Giriwijoyo, 2006). Secara fisiologis, volume darah yang dimiliki laki-laki kurang lebih satu liter lebih banyak daripada perempuan dan laki-laki memiliki volume paru -paru $10 \%$ lebih besar dibandingkan perempuan (Nopembri, 2010), yang artinya adalah pemenuhan nutrisi dan oksigen yang dialirkan ke sel otak jauh lebih besar laki-laki daripada perempuan hal tersebut sangat bermanfaat dalam mempertahankan fungsi sel otak.

Rata-rata usia pada kelompok pra lansia 58,13, rerata pada kelompok lansia 67,73 dan rerata pada kelompok lansia tua 79,53. Hasil penelitian Watson (2003) menyatakan bahwa lansia yang berumur 60 tahun keatas prevalensi terjadinya demensia akan meningkat dua kali lipat setiap kenaikan 5 tahun usia lansia, hal tersebut juga sesuai dengan yang disampaikan oleh Japardi (2003) semakin bertambah umur maka semakin besar prevalensi dan semakin berat tipe demensia yang dialami lansia ini disebabkan karena umur merupakan faktor resiko mayor terjadinya demensia. Hal yang sama ditunjukkan pada penelitian yang dilakukan oleh Mongisidi (2013), dimana individu yang masuk dalam kategori usia tua (75-90 tahun) memiliki rata-rata persentasi kognitif tidak normal, sehingga disimpulkan semakin tua usia seseorang, maka fungsi kognitif individu cenderung menurun.

Pada usia lansia terjadi penurunan fungsi sel- sel otak, menurut Nugroho (2014), atropi yang terjadi pada otak akibat penuaan menyebabkan penurunan hubungan antarsaraf, mengecilnya saraf panca indra sehingga waktu respon dan waktu bereaksi melambat, deficit memori, gangguan pendengaran, penglihatan, penciuman, dan perabaan. Menurunya daya pendengaran pada telinga dalam, terutama terhadap nada tinggi, suara tidak jelas, sulit mengerti kata-kata, 50\% terjadi pada orang di atas umur 65 tahun. Hal ini sesuai pendapat Sadock (2007) dalam Kanditamahran (2016), neurotransmiter yang paling berperan dalam patofisiologi dari demensia Alzheimer adalah asetilkolin dan norepinefrin. Keduanya dihipotesis menjadi hipoaktif pada penyakit demensia Alzheimer. Beberapa penelitian melaporkan pada penyakit Alzheimer ditemukannya suatu degenerasi spesifik pada neuron kolinergik pada nukleus basalis meynert. Data lain yang mendukung adanya defisit kolinergik pada Alzheimer adalah ditemukan konsentrasi asetilkolin dan asetil kolin transferase menurun.

\section{Gambaran Tingkat Demensia Pada Kelompok Umur Lansia Sebelum dan Setelah Diberi Senam Otak}

Berdasarkan hasil penelitian diketahui bahwa tingkat demensia pada lansia sebelum diberikan senam otak yaitu terbanyak pada probable kognitif pada kelompok pra lansia 15 responden, lansia 15 responden dan lansia tua 14 responden. Hasil ini sesuai dengan yang dilakukan Lisniani (2010), bahwa senam otak dapat meningkatan fungsi kognitif dengan nilai yang signifikan sebelum 9,15 dan sesudah 15,85 dengan 
selisih 6,7 dengan penelitian sebelumnya yang menyatakan bahwa senam otak dapat meningkatkan daya ingat lansia dengan nilai signifikan yaitu $\mathrm{p}=0,005(\mathrm{p}<0,05)$ (Paula 2010), hal ini didasari oleh Tilarso (2007), menyatakan pelatihan dengan frekuensi tiga kali seminggu adalah sesuai untuk lansia yang berusia lebih dari 60 tahun serta penelitian lain seperti yang dilakukan Rohmat (2014), mengatakan bahwa terdapat perbedaan nilai kognitif sebelum tindakan senam otak dengan scor tertinggi sebanyak nilai kognitif sedang sebanyak 7 responden (33\%) dan setelah tindakan senam otak score nilai kognitif ringan sebanyak 8 responden $(53 \%)$.

Menurut hasil penelitian Affendi (2014), bahwa aktivitas fisik berperan dalam fungsi aktivitas fisik, terdapat unsur gerak. Bergerak berfungsi untuk menyiapkan otak untuk belajar secara optimal. Dengan bergerak, aliran darah ke otak lebih tinggi sehingga suplai nutrisi lebih baik. Otak membutuhkan nutrisi terutama berupa oksigen dan glukosa. Glukosa bagi otak merupakan bahan bakar utama supaya otak dapat bekerja optimal. Setiap kali seseorang berpikir akan menggunakan glukosa. Kurangnya suplai oksigen ke otak dapat menimbulkan disorientasi, bingung, kelelahan, gangguan konsentrasi, dan masalah daya ingat.

Berdasarkan hasil penelitian setelah dilakukan tindakan terbanyak masih berada pada tingkatan probable kognitif, namun penurunan terbanyak terjadi pada kelompok pra lansia dari 15 responden menjadi 6 responden. Hal ini bisa dipahami bahwa kelompok pra lansia ini belum banyak mengalami demensia dibandingkan dengan kelompok lansia dan lansia tua. Hasil penelitian Watson (2003), menyatakan bahwa lansia yang berumur 60 tahun keatas prevalensi terjadinya demensia akan meningkat dua kali lipat setiap kenaikan 5 tahun usia lansia, hal tersebut juga sesuai dengan yang disampaikan oleh Japardi (2003), semakin bertambah umur maka semakin besar prevalensi dan semakin berat tipe demensia yang dialami lansia ini disebabkan karena umur merupakan faktor resiko mayor terjadinya demensia.

Hasil ini serupa dengan penelitian yang dilakukan oleh Festi (2010), menunjukan nilai kognitif sebelum diberikan senam otak adalah kognitif sedang sebanyak (60\%), serupa dengan hal tersebut menurut Padila (2013), dikatakan terjadi kemunduran kognitif antara lain suka lupa, ingatan tidak berfungsi baik, ingatan terhadap hal-hal dimasa muda lebih baik dari pada yang baru saja terjadi, sering adanya disorientasi terhadap waktu, tempat dan orang, sulit menerima ide-ide baru.

\section{Analisis Perbedaan Skor Demensia}

Hasil uji Man Whitney menunjukkan bahwa secara statistik sebelum dan setelah diberi senam otak ketiga kelompok berubah secara bermakna. Karena pra lansia vs lansia berbeda, pra lansia vs lansia tua berbeda, dan lansia vs lansia tua juga berbeda dan membuat angka menjadi kecil yaitu lansia tua karena ketika semua di vs dengan lansia tua tingkat signifikan menjadi lebih kecil. Sehingga dapat disimpulkan bahwa lansia tua membuat hasil perbedaan yang signifikan dengan nilai $p<0,001$. Hal ini terjadi karena lansia tua tingkat demensia lebih parah, pada lansia dan lansia tua sudah banyak yang demensia semakin parah maka jika disandingkan dengan pra lansia sangat bermakna perbedaannya lebih besar namun angka signifikannya lebih kecil. 
Pada penelitian ini dapat mengubah pada pra lansia dan lansia sementara pada lansia tua justru tidak berubah lebih banyak dilihat dari penurunan dari probable menjadi normal sebanyak 9 responden. Perubahan ini dimungkinkan karena efek dari intervensi senam otak. Menurut teori yang dikemukakan oleh seorang ahli yang menemukan gerakan senam otak di Amerika menyatakan bahwa terapi senam otak yang dilakukan selama 2 x sehari dalam 15 menit selama 3 minggu, secara teratur dapat mengurangi terjadinya penurunan fungsi kognitif Denisson (2009). Dengan dilakukan gerakan senam otak maka setiap gerakan fisik yang dilakukan memberikan rangsangan kepada otak, dengan menurunnya aktivitas maka rangsangan kepada otak juga berkurang. Karena otak memiliki sifat plastisitas dimana bila terus diberikan rangsangan, fungsinya akan tetap terjaga dan sebaliknya bila rangsangan tersebut kurang atau tidak ada, proses plastisitas tidak terjadi dan otak akan mengalami penurunan struktur dan fungsinya (Nugroho, 2014).

Sapardjiman (2007), menyatakan bahwa senam otak juga bermanfaat untuk membuka bagian-bagian otak yang sebelumnya tertutup atau terhambat sehingga kegiatan belajar atau bekerja berlangsung menggunakan seluruh otak (Whole Brain), mengurangi stress emosional dan pikiran lebih jernih, menjadikan orang lebih bersemangat, lebih konsentrasi, lebih kreatif dan efisien, kemampuan berbahasa dan daya ingat meningkat, hubungan antar manusia dan suasana belajar/bekerja lebih rileks dansenang.

Tilarso (2007), menyatakan pelatihan dengan frekuensi tiga kali seminggu adalah sesuai untuk lansia yang berusia lebih dari 60 tahun serta penelitian lain seperti yang dilakukan Rohmat (2014), mengatakan bahwa terdapat perbedaan nilai kognitif sebelum tindakan senam otak dengan scor tertinggi sebanyak nilai kognitif sedang sebanyak 7 responden (33\%) dan setelah tindakan senam otak score nilai kognitif ringan sebanyak 8 responden $(53 \%)$.

\section{SIMPULAN}

Tingkat demensia sebelum dilakukan senam otak terbanyak ada pada tingkatan probable cognitive namun setelah dilakukan tindakan terjadi perubahan sebagian besar ada pada kelompok pra lansia menjadi kategori normal sedangkan lansia dan lansia tua masih pada tingkatan probable congnitive. Ada pengaruh senam otak terhadap penurunan tingkat demensia pada lansia dimana selisih terbanyak ada pada lansia atau pra lansia. Hasil penelitian ini diharapkan dapat dijadikan sumber informasi dalam penelitian selanjutnya serta tindakan lain seperti terapi kognitif untuk mengoptimalkan fungsi kognitif pada kelompok uusia lanjut dengan demensia.

\section{REFERENSI}

Azizah. (2011). Keperawatan Lanjut Usia. Yogyakarta : Graha Ilmu

Guslinda, Yolanda, Y. \& Delvi Hamdayani (2013) 'Pengaruh senam otak terhadap fungsi kognitif pada lansia dengan dimensia di panti sosial tresna werdha sabai nan aluih sicincin padang pariaman tahun 2013'.

Lilik Ma'rifatul Azizah (2011). Keperawatan Lanjut Usia Edisi I. Yogyakarta : Graha Ilmu.

Maryam, R. S. (2008). Mengenal Usia Lanjut dan Perawatannya. Jakarta : Salemba Medika. 
Mongisidi, R. (2013). Profil Penurunan Fungsi Kognitif pada Lansia di Yayasan Yayasan Manula di Kecamatan Kawangkoan. Manado : FK Unsrat.

Nugroho, W. (2014). Keperawatan Gerontik Dan Gerantrik Edisi 3. Jakarta: EGC.

Padila. (2013). Kepewawatan Gerontik. Yogyakarta: Nuha Medika.

Sarifah (2016) 'Pengaruh Senam Otak (Brain Gym) Terhadap Penurunan Tingkat

Demensia Pada Lansia', Keperawatan Notokusumo, IV(1), pp. 47-53.

Tilarso, H. (2007). Gender dan Seksualitas. www.bkkbn.go.id. 23 Februari 2018.

Watson. (2003), Perawatan Pada Lansia, EGC, Jakarta.

Zulaini. (2016). Manfaat Senam Otak. Fakultas ilmu keolahragaan. Medan: UNIMED. 